\title{
Seasonal variation in the frequency of anencephalus and spina bifida births in the United Kingdom
}

\author{
MALCOLM H MACLEAN AND ALAN MACLEOD
}

From the Lothian Health Board, Community Health Services, Edinburgh EH1 2PP, and Napier College, Edinburgh EH10 5DT, UK

SUMMARY There have been statistically significant seasonal variations of annencephalus and spina bifida in each country of the United Kingdom during 1964-79 with the exception of anencephalus births in Northern Ireland. The seasonal peaks, where discernible, are in phase. Embryos appear to develop anencephalus most commonly in May-June and spina bifida in July.

Anencephalus and spina bifida (ASB) vary in frequency according to a complicated epidemiological pattern. Geographical, seasonal, and secular variations are known to occur. ${ }^{1}$ These defects occur more commonly in women at the extremes of reproductive life and in social classes IV and V. ${ }^{2}$ Environmental factors such as variation in diet and exposure to drugs have been reported, ${ }^{1}$ and more recently protective effects of folic acid and vitamin $C$ against neural tube defects have been suggested. ${ }^{34}$ Genetic factors, probably polygenic, may also be important. ${ }^{5}$

\section{Reasons for present study}

A statistically significant seasonal variation in the frequency of anencephalus and spina bifida births in England and Wales from 1964 to 1972 has been reported. The date of the last menstrual period (LMP) of mothers giving birth to anencephalics, as derived from the birth data, was estimated to occur most commonly in April. The corresponding season for spina bifida was April-June. ${ }^{2}$

The purposes of our study were to examine the seasonal variation of ASB in individual provinces of the United Kingdom to discover if each showed seasonality, whether the seasonality was in phase, and whether the statistical significance of the seasonality was homogeneous, and also to establish when was the commonest time of year for these defects to develop.

\section{Subjects and methods}

Notifications of anencephalus and spina bifida births were obtained from the responsible data collecting agencies of England and Wales (Office of Population Censuses and Surveys), Scotland (Common Services
Agency), and Northern Ireland (DHSS). (J Weatherall, J Clark, and J Walby: personal communications). These data provided the number of ASB births each month for each country for the periods 1964-79, 1964-78, and 1964-78 respectively. In England and Wales and in Scotland birth notifications, whether ASB or otherwise, are recorded by these agencies as the date of the registration of the birth and not of the date of birth itself. In Northern Ireland both are recorded as the date of birth. Most births, however, ASB or otherwise, are thought to be registered within three or four days of birth.

Data on the numbers of live births registered in England and Wales, Scotland, and Northern Ireland were obtained respectively from the Office of Population Censuses and Surveys and from the General Registrar Offices of Scotland and Northern Ireland. These figures were related to the numbers of live births registered rather than to the total births used in previous studies, ${ }^{2}$ because monthly stillbirth statistics are not available for Northern Ireland.

\section{ANALYSIS OF DATA}

The raw data were analysed by the method of Walter and Elwood ${ }^{6}$ and by the rank sum test described by Hewitt et al. ${ }^{7}$

A second set of data was prepared taking into account the shorter mean lengths of gestation of anencephalus and spina bifida pregnancies reported in England and Wales 1964-72: 35. 1 weeks and 38.5 weeks compared with 40.1 weeks in other pregnancies. ${ }^{2}$ Using this information dates of LMPs preceding ASB and unaffected pregnancies were calculated. These data were analysed in a similar fashion to the raw data. 


\section{Results}

The results are summarised in tables 1 and 2 and illustrated in the figure. Each point on the graph represents the ratio of the frequency of the defect that month to the mean annual frequency of that defect.

Table 1 Analyses of seasonal variation of ASB births by the methods of Walter and Elwood (table 1A) and Hewitt et al (table 1B).

Table 1A

\begin{tabular}{|c|c|c|c|c|}
\hline & $\begin{array}{l}\text { Time of peak } \\
\text { of births }\end{array}$ & Amplitude & $x^{2}$ & Significance \\
\hline $\begin{array}{l}\text { Spina bifida } \\
\text { England and Wales } \\
\text { Scotland } \\
\text { Northern Ireland }\end{array}$ & $\begin{array}{l}4 \mathrm{Mar} \\
20 \mathrm{Feb} \\
13 \mathrm{Mar}\end{array}$ & $\begin{array}{l}0.0642 \\
0.0765 \\
0.0760\end{array}$ & $\begin{array}{r}61 \cdot 69 \\
8 \cdot 95 \\
7 \cdot 38\end{array}$ & $\begin{array}{l}p<0.001^{\circ} \\
p<0.025^{*} \\
p=0.025^{\circ}\end{array}$ \\
\hline $\begin{array}{l}\text { Anencephalus } \\
\text { England and Wales } \\
\text { Scotland } \\
\text { Northern Ireland }\end{array}$ & $\begin{array}{l}7 \text { Jan } \\
15 \text { Dec } \\
10 \text { Dec }\end{array}$ & $\begin{array}{l}0.0839 \\
0.1393 \\
0.0999\end{array}$ & $\begin{array}{r}50 \cdot 72 \\
20 \cdot 44 \\
1.99\end{array}$ & $\begin{array}{l}p<0.001^{*} \\
p<0.001^{*} \\
p>0.1\end{array}$ \\
\hline
\end{tabular}

Table 1B

\begin{tabular}{|c|c|c|c|}
\hline & Max Rank sum & Significance & $\begin{array}{l}\text { Six month period } \\
\text { giving maximum }\end{array}$ \\
\hline $\begin{array}{l}\text { Spina bifida } \\
\text { England and Wales } \\
\text { Scotland } \\
\text { Northern Ireland }\end{array}$ & $\begin{array}{l}56 \\
53 \\
56\end{array}$ & $\begin{array}{l}0.025^{*} \\
0.126 \\
0.025^{*}\end{array}$ & $\begin{array}{l}\text { Dec-May } \\
\text { Jan-June } \\
\text { Dec-May }\end{array}$ \\
\hline $\begin{array}{l}\text { Anencephalus } \\
\text { England and Wales } \\
\text { Scotland } \\
\text { Northern Ireland }\end{array}$ & $\begin{array}{l}56 \\
54 \\
49\end{array}$ & $\begin{array}{l}0.025^{*} \\
0.077 \\
0.496\end{array}$ & $\begin{array}{l}\text { Nov-Apr } \\
\text { Sep-Feb } \\
\text { Aug-Jan }\end{array}$ \\
\hline
\end{tabular}

"Indicates statistically significant result.

During the periods studied, the frequencies of anencephalus in England and Wales, Scotland, and Northern Ireland per 1000 live births were $1 \cdot 3,2 \cdot 1$, and $3 \cdot 1$, the corresponding figures for spina bifida were $1 \cdot 8,2 \cdot 8$, and $3 \cdot 6$.

\section{Discussion}

South Wales has been reported to show no seasonal variation of ASB births. ${ }^{8}$ Anencephalic births in Northern Ireland and South Wales have been noted to be commoner than in most other places. Our data, taken with these findings and those of other European studies (table 3), suggest that prevalence tends to be slight in all seasons in places where the defects are uncommon, great in all seasons where they are common and subject to seasonal variation, maximum in winter, in intermediate situations. This
Table 2 Analysis of seasonal variation of birth data transformed to the time of the last menstrual period (LMP) taking into account different durations of gestation of anencephalus, spina bifida, and unaffected pregnancies: analysis by the methods of, Walter and Elwood (table 2A) and Hewitt et al (table 2B)

Table 2A

\begin{tabular}{|c|c|c|c|c|}
\hline & $\begin{array}{l}\text { Time of peak } \\
\text { of LMPs }\end{array}$ & Probability & Amplitude & $x^{2}$ Value \\
\hline \multicolumn{5}{|l|}{ Spina bifida } \\
\hline England and Wales & 11 June & $\mathrm{p}<0.001^{*}$ & 0.0649 & $54 \cdot 29$ \\
\hline Scotland & 29 May & $\mathrm{p}<0.025^{*}$ & 0.0739 & $7 \cdot 61$ \\
\hline Northern Ireland & (22 June) & $0.05<p<0.1$ & - & $5 \cdot 86$ \\
\hline \multicolumn{5}{|l|}{ Anencephalus } \\
\hline England and Wales & 9 May & $\mathrm{p}<0.001^{*}$ & 0.0376 & 23.90 \\
\hline Scotland & 8 April & $p<0.001^{*}$ & 0.0999 & $14 \cdot 24$ \\
\hline Northern Ireland & - & $p>0.30$ & - & $1 \cdot 46$ \\
\hline
\end{tabular}

Table 2B

\begin{tabular}{|c|c|c|c|}
\hline & Max Rank Sum & Probability & $\begin{array}{l}\text { Six month period } \\
\text { giving maximum }\end{array}$ \\
\hline \multicolumn{4}{|l|}{ Spina bifida } \\
\hline England and Wales & 56 & $0.0248^{*}$ & Apr-Sep \\
\hline Scotland & 52 & 0.1914 & Apr-Sep \\
\hline Northern Ireland & 57 & $0.0134^{*}$ & Apr-Sep \\
\hline \multicolumn{4}{|l|}{ Anencephalus } \\
\hline England and Wales & 57 & $0.0134^{*}$ & Feb-Jul \\
\hline Scotland & 53 & $0 \cdot 126$ & Jan-Jun \\
\hline Northern Ireland & 52 & $0 \cdot 191$ & Dec-May \\
\hline
\end{tabular}

*Indicates statistically significant result.

relation does not hold universally, however, and in some places there has been dissociation of the seasonal variation of anencephalus and spina bifida-for instance, in Hungary where a seasonal variation of spina bifida but not of anencephalus has been reported and in Birmingham during the 1940s where the converse was found. ${ }^{19}$ Different reports on the seasonal variation of ASB births must be compared cautiously: the different lengths of ASB and normal pregnancies and also seasonal variations of all births have been taken into account in some studies but not in others. ${ }^{12}$

Turning to temporal differences in seasonal variation there is some evidence to suggest that during years when anencephalic births have been particularly common, the seasonal variation has changed. In Birmingham around 1954 and in Scotland around 1960 the frequency of anencephalus increased and the usual seasonal pattern disappeared. This was due in part to the increase in summer births of anencephalics. This did not hold during the early 1940s in Birmingham, however, when the frequency of anencephalus was also great. ${ }^{19}$

The $\chi^{2}$ values obtained by analysing the refined data were less than those obtained from the raw data. 
Anencephalus - S Spina bifida

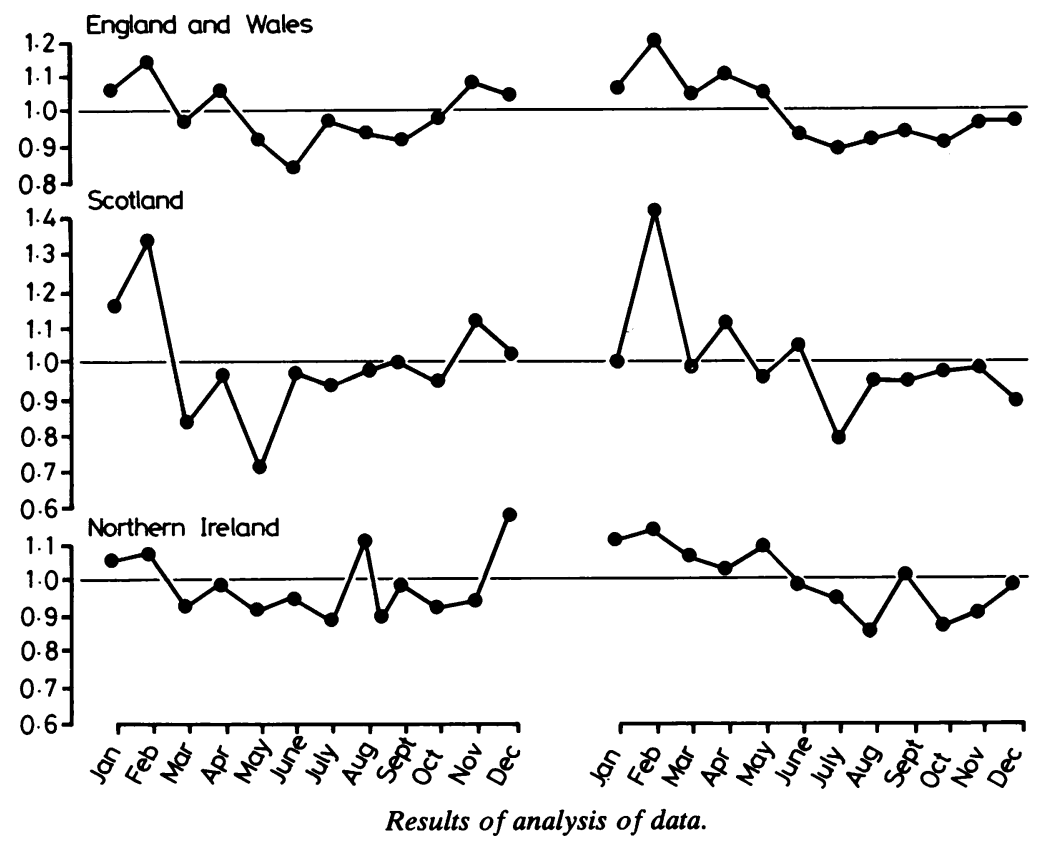

On the other hand, comparing the results of analyses of the two sets of data by the method of Hewitt et al, it can be seen that using the refined data the sector of the calendar into which the peaks for each defect fall, is reduced.

The peaks of the seasonal patterns in the provinces where they are discernible are in phase.

The Walter and Elwood test provides more precise information than that provided by the test described by Hewitt et al, the limitations of which were described by the authors. The most interesting results are those obtained by applying the Walter and
Elwood test to the data transformed to the estimated time of the last menstrual period (LMP) preceding the pregnancies. The LMP usually precedes conception by about two weeks and, when anencephalus and spina bifida defects develop in the embryo, they are thought to do so at about the fourth week of gestation. It therefore appears that, where a seasonal variation is discernible, embryos tend to develop anencephalus most commonly during May and June and, in the case of spina bifida, July. This seems to be a fairly consistent pattern throughout the United Kingdom.

Table 3 Seasonal variation of ASB births in European countries other than the United Kingdom

\begin{tabular}{|c|c|c|c|c|c|c|c|}
\hline & $\begin{array}{l}\text { Statistically significant } \\
\text { seasonal variation? }\end{array}$ & $\begin{array}{l}\text { Period of peak frequency } \\
\text { of abnormal births }\end{array}$ & Period of study & $\begin{array}{l}\text { Hospital }(H) \text { or } \\
\text { population }(P) \text { sample }\end{array}$ & $\begin{array}{l}\text { No of births } \\
\text { analysed }\end{array}$ & $\begin{array}{l}\text { Frequency of defect } \\
\text { per } 1000 \text { births }\end{array}$ & Reference \\
\hline $\begin{array}{l}\text { Anencephalus } \\
\text { Germany (Münster) } \\
\text { Netherlands } \\
\text { Italy (Milan) } \\
\text { Sweden } \\
\text { Germany (Münster) } \\
\text { Hungary } \\
\text { Norway } \\
\text { France } \\
\text { USSR } \\
\text { Finland }\end{array}$ & $\begin{array}{l}\text { Yes } \\
\text { Yes } \\
\text { Yes } \\
\text { Yes } \\
\text { No } \\
\text { No } \\
\text { No } \\
\text { No } \\
\text { No } \\
\text { No }\end{array}$ & $\begin{array}{l}\text { Jan-Feb } \\
\text { April } \\
\text { Jan-April } \\
\text { April } \\
\text { Winter months } \\
\text { - } \\
- \\
- \\
- \\
-\end{array}$ & $\begin{array}{l}1950-61 \\
1951-68 \\
1937-64 \\
1965-72 \\
1950-56 \\
1963-67 \\
1951-65 \\
1945-55 \\
1970-76 \\
1965-73\end{array}$ & $\begin{array}{l}\mathbf{P} \\
\mathbf{P} \\
\mathbf{H} \\
\mathbf{H} \\
\mathbf{P} \\
\mathbf{P} \\
\mathbf{P} \\
\mathbf{H} \\
\mathbf{H} \\
\mathbf{P}\end{array}$ & $\begin{array}{r}502363 \\
4335104 \\
220545 \\
- \\
271000 \\
94878 \\
947440 \\
746276 \\
282336 \\
621026\end{array}$ & $\begin{array}{c}1 \cdot 27 \\
1 \cdot 18 \\
0 \cdot 59 \\
1 \cdot 33 \\
1 \cdot 10 \\
0.98 \\
0 \cdot 54 \\
0 \cdot 33 \\
0.32\end{array}$ & $\begin{array}{r}9 \\
10 \\
11 \\
12 \\
13 \\
14 \\
15 \\
16 \\
17 \\
18\end{array}$ \\
\hline $\begin{array}{l}\text { Spina bifida } \\
\text { Hungary } \\
\text { Germany (Münster) } \\
\text { Italy } \\
\text { Sweden }\end{array}$ & $\begin{array}{l}\text { Yes } \\
\text { No } \\
\text { No } \\
\text { No }\end{array}$ & $\begin{array}{l}\text { March } \\
\text { Winter months } \\
- \\
-\end{array}$ & $\begin{array}{l}1963-67 \\
1950-56 \\
1937-64 \\
1965-72\end{array}$ & $\begin{array}{l}\mathbf{P} \\
\mathbf{P} \\
\mathbf{H} \\
\mathbf{H}\end{array}$ & $\begin{array}{c}692670 \\
271000 \\
220545 \\
-\end{array}$ & $\begin{array}{r}1 \cdot 63 \\
2 \cdot 28 \\
0 \cdot 70 \\
-\end{array}$ & $\begin{array}{l}14 \\
13 \\
11 \\
12\end{array}$ \\
\hline
\end{tabular}


We are grateful to the following organisations which provided data for this study: the Office of Population Censuses and Surveys, London; Common Services Agency, Edinburgh; Department of Health and Social Security, Belfast; and the Offices of the Registrars General of Scotland and Northern Ireland.

Reprints are not available from the authors.

\section{References}

${ }^{1}$ Leck I. Causation of neural tube defects: clues from epidemiology. Br Med Bull 1974; 30: 158-63.

${ }^{2}$ Rogers SC, Weatherall JAC. Anencephalus, spina bifida and congenital hydrocephalus. England and Wales 1964-72. London: HMSO, 1976.

${ }^{3}$ Smithells RW, Shepperd S, Schorah CJ. Vitamin deficiencies and neural tube defects. Arch Dis Child 1976; 51; 944-50.

'Smithells RW, Shepperd S, Schorah CJ, et al. Possible prevention of neural tube defects by periconceptional vitamin supplementation. Lancet 1980; i: 339-40.

${ }^{5}$ Carter CO. Genetics of common single malformations. $\mathrm{Br}$ Med Bull 1976; 32: 21-6.

- Walter SD, Elwood JM. Test of seasonality of events with a variable population at risk. Br J Prev Soc Med 1975; 29: 18-21.
${ }^{7}$ Hewitt D, Milner J, Csima A, Pakula A. On Edwards' criterion of seasonality and a non-parametric alternative. Br J Prev Soc Med 1971; 25: 174-6.

${ }^{8}$ Lawrence KM, Carter CO, David PA. Major central nervous system malformations in South Wales. II. Pregnancy factors, seasonal variation and social class effects. Br J Prev Soc Med 1968; 22: 212-22.

${ }^{9}$ Tunte W. Zur haufigkeit angeborener misbildungen des zentral nervensystems und des verdauungstraktes in den jahren 1950-61. Humangenetik 1968; 6: 29-33.

${ }^{10}$ Overbeke J. Anencephalie in Nederland 1951-68. Netherlands: Statanitgererj, 1971.

${ }^{11}$ Beolchini PE, Bailo U. Sull 'esistenza di variazioni stagionali della frequenza dell, anencefalia. Minerva Ginecol 1965; 17: 928-34.

${ }^{12}$ Sandall B. Seasonal incidence of some congenital malformations in the central nervous system in Sweden 1965-1972. Acta Paediatr Scand 1977; 66: 65-72.

${ }^{13}$ Tunte $W$. Zur haufigkeit der anencephalie und spina bifida aperta im regierungsbezirk Münster. Zeitschrift für Menschliche Vererbungs und Konstitutionslehre 1964, 37: 525-30.

${ }^{14}$ Czeizel A, Revesz C. Major malformations of the central nervous system in Hungary. Br J Prev Soc Med 1970; 24: 205-22.

${ }^{15}$ Westland K. Mortality from congenital malformations of the central nervous sytem in Norway, 1951-65. Br J Prev Soc Med 1969; 23: 28-33.

${ }^{16}$ Frezal J, Guillemot MC, Lamy M. Anencephaly in France. Am J Hum Genet 1964; 16: 336-50.

${ }^{17}$ Prytkov AN. Population incidence of neural tube defects in Moscow. Genetika 1978; 14: 1461-5.

${ }^{18}$ Granroth G, Hakama M, Saxen L. Defects of the central nervous system in Finland: $I$. Variation in time and space, sex distribution and parental age. Br J Prev Soc Med 1977; 31: 164-70.

${ }^{19}$ Leck I, Record RG. Seasonal incidence of anencephalus. Br J Prev Soc Med 1966; 20: 67-75. 